\title{
TEACHING READING COMPREHENSION USING TEAM ACCELERATED INSTRUCTION (TAI) TECHNIQUE
}

\author{
Euis Setiati \\ Ikip Siliwangi \\ Euis Setiati@yahoo.co.id \\ Intan Satriani \\ Ikip Siliwangi \\ Intan.satriani@yahoo.co.id
}

\begin{abstract}
This study aims at examining whether students' reading comprehension can be improved by using Team Accelerated Instruction (TAI) technique. This research used pre experimental design with one group pretest and post-test. The sample of this research was 34 students of tenth grade of SMK Pasundan 1 Cimahi in academic year $2017 / 2018$. The instrument of this research was test which consist of multiple choice question. The data of this research was collected by giving reading comprehension test to students. The collected data of this research was analyzed using SPSS program. Then, the result of data analysis showed that mean of pretest 55.59 and after the implementation of Team Accelerated Instruction (TAI) technique the mean of posttest became 67.79. It shows that there are significant differences between pretest and posttest. Based on the data analysis, the null hypothesis was rejected. In other words, teaching reading comprehension using Team Accelerated Instruction (TAI) technique had significance improvement on students' reading comprehension. The implementation of Team Accelerated Instruction (TAI) technique in teaching reading comprehension was able to resolve those difficulties since it required the students to share, discuss, and unite their thought or problem on comprehending the content of the text with other members of their group.
\end{abstract}

Keywords:Reading Comprehension, Team Accelerated Instruction (TAI) Technique.

\section{A. INTRODUCTION}

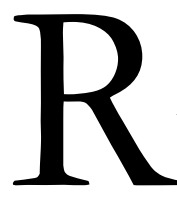

eading is one of the main skills in English that plays important role. Students get information and ideas which they need to know. Moreover, students can know what they do not know before. Reading is a process in which done by reader to get message or information from the writer through printed media (Tarigan, 2008). In addition, based on Goodman (1980), reading comprehension is a redundant phrase, because without comprehension reading has not truly happened.In teaching reading, there are some problems that can be identified in this research.

Based prelimenary study, some high school teachers in Bandung convey that it is rather hard to teach reading comprehension to learners. It is stated that they are still confuse finding an appropriate method and media to apply in teaching reading comprehension for learners. English has been taught in all levels of Indonesian educational units, recently from kindergarten school, elementary school, junior high school, senior high school up to university. 
Euis Setiati, Intan Satriani, Teaching Reading Comprehension ...

Moreover, the problems found related to the reading comprehension are students who are lack of vocabularies and background knowledge to understand the text, lack of communication between students and teacher, lack of cooperation between student and other students.

In addition, the teachers also found problems in teaching reading such as the use of technique which is not appropriate for students in senior high school. Teachers used the techniques that cannot motivate students and make students involved in learning. Based on the problems, therefore, the researcher proposed Tai techniques in teaching reading comprehension.

\section{B. REVIEW OF LITERATURE}

Team Accelerated Instruction technique is defined as group work of different level, gender, and ethnicity (Slavin, 1987). He also states that in implementing Team Accelerated Instruction (TAI) technique, students do different units and work in a team. Then, they do peer checking and help one another with any problem. Then without help, they take final units tests that are scored by student monitors. Students are motivated to work with one another on these activities through the use of cooperative reward.Team Accelerated Instruction (TAI) is adapt teaching to individual differences with regard to students' abilities and student achievement. In addition, to solving motivational problems in individual teaching techniques, Team Accelerated Instruction (TAI) is designed to derive enormous benefits from the potential socialization contained in cooperative learning.

TAI is one of the type of Cooperative Learning.According to Slavin(2013) Cooperative Learning is learning done in groups, students in one class are made into small groups of 4 to 5 people to understand the concept facilitated by the teacher. Cooperative Learning model is a model of learning with the setting of small groups by considering the diversity of group members as a forum for students to work together and solve a problem through social interaction with peers, providing opportunities for learners to learn something well at the same time and he became resource person for another friend.

\section{METHOD}

This research method used quantitative to examine the instrument and teaching techniques given to students by collecting and statistically analyzing data that are in numeric form.Based on Kaswan \& Suprijadi (2013), quantitative research is deductive theory-based research process that focuses primarily on testing theories and specific research hypotheses that consider finding differences and relationships using numeric data and statistical methods to make specific conclusions about the phenomena.The researcher used Pre-Experimental design in this 
research. Fraenkel, Wallen, \& Hyun(2012)stated that pre-experimental research or experiment refers toresearch in which at least one independent variable. For this research, the teaching treatment was given for five meetings, in each treatment the students is guided to comprehension the text using team accelerated instruction technique. In testing, the students were given a pre-test before the treatment and post-test after the treatment. The result of pretest and post-test were compared and calculated to find out how far using team accelerated instruction technique for student' reading comprehension.

\section{Population and Sample}

\section{Population}

Population is a group of individuals who have the same characteristic (Creswell, 2012). The population of this research was students at tenth grade of SMK Pasundan 1 Cimahi in the academic year 2017/2018. It is located in Jl. Encep Kartawiria No.97/A Citeureup, Cimahi Utara. The researcher chose tenth grade which consist of 194 students divided into seven classes.

\section{Sample}

Sample is a subgroup of the target population that the writer plans to study for generalizing about the target population (Creswell, 2012). From all student of the tenth grade of SMK Pasundan 1 Cimahi in the academic year 2017/2018, the researcher chose the sample in this research one class (34 students) of the 10-AK.

\section{Instrument}

Instrument is also important, it is device to get the data. It should be chosen according to the data we need. It is needed to get result, so the researcher get a conclusion. As it is commonly known, this research was made to know the effectiveness of previewing technique in student reading comprehension using team accelerated instruction technique, so the writer needs amount data. In the process of gathering the data, firstly the writer do the observation to the school before the writer do the research, then the writer gave test to know the students' reading comprehension using narrative text as pretest before giving the treatment using team accelerated instruction, and posttest was given after the students got the treatment.The writer gave test about narrative text matter consisting of 20 multiple choices in the pretest and posttest.

\section{Data Collection Technique}

The procedures of data collecting used in this research are pretest and posttest. The writer gave the pretest to the students before teaching learning process started, and posttest gave to the students at the last meeting. The pretest and the scoring were similar with the posttest. However, the post-test was given after the treatment had been done.After the data were collected, they were processed and analyzed by using statistic calculation of SPSS. SPSS is the 
Euis Setiati, Intan Satriani, Teaching Reading Comprehension ...

acronym of statistical packages which can perform highly complex data manipulated and analysis with sample instrument it is designed for both interactive and non-interactive (batch) uses. As it has stated in the procedure of analyzing the data, the first step researcher did was computing the difference between the score of pretest and posttest. The pretest and posttest were conducted to find the score of the students before and after the strategy was applied. The analyze of the data using SPSS statistics 22. In line with Dornyei(2007),nowadays the mathematical aspects of quantitative data analysis are largely to the computer, and several statistical programs have been to developed to direct the computer's work.

\section{RESULTS AND DISCUSSION}

\section{Results}

\section{Validity and Reliability Test}

Based on the result of validity test for multiple choice for writer's instrument, the writer was used twenty valid items as a matter of pretest and posttest. The result of reliability test for multiple choice test has a reliability coefficient of 0,667. Based on Guilford (1956), criteria coefficient correlation reliability test will be good if $>0,4$. So, reliability coefficient of 0,414 is reliable.

\section{Result of Pretest and Posttest}

In this research, before the writer collected the score of posttest, the writer gave treatments for five meeting to recognize the students' reading comprehension after using Team Accelerated Instruction (TAI) technique.

\section{PretestScore}

Pretest scores from students were the first collected data after conducting the experimental test which indicated the validity and reliability of instrument.The pretest scores showed original reading comprehension of students before given Team Accelerated Instruction (TAI) technique in treatment part. The detail of students' pretest score can be seen from the following table 2

Table 1. Scores of Pretest

\begin{tabular}{|c|c|}
\hline Category & Data \\
\hline $\mathrm{N}$ (Students) & 34 \\
\hline Highest Score & 75 \\
\hline Lowest Score & 35 \\
\hline Sum & 1890 \\
\hline
\end{tabular}




\begin{tabular}{|c|c|}
\hline Mean & 55.59 \\
\hline Std. Deviation & 9.274 \\
\hline
\end{tabular}

Table above shows the score of pretest. There are 34 students of tenth grade senior high school. In the pretest, there are score below the minimum criteria, it indicates that some students have difficulty in answering the instrument given the writer. Based on the table, the highest score is 75 and the lowest score is 35 . Total score in pretest is 1890 and mean score of pretest is 55,59 .

\section{Tests of Normality for Pretest Score}

Test of normality is the most widely used to measure variability a set of data in inferential statistical procedures. It was showed to check whether the distributions of pretest scores of students are normally distributed or not. Therefore, the Kolmogorov-Smirnov Normality test was used with level sig. $\alpha=0.05$. The hypothesis of this test is:

$\mathrm{H}_{0}=$ the score of pretest and posttest are normally distributed.

The results of Normality Test of Pretest are presented below:

Table 2. Normality Test of Pretest

\begin{tabular}{|c|c|c|c|}
\hline \multirow{2}{*}{} & \multicolumn{3}{|c|}{ Kolmogorov-Smirnov $^{\mathrm{a}}$} \\
\cline { 2 - 4 } & Statistic & $\mathrm{df}$ & Sig. \\
\hline pretest & .153 & 34 & .041 \\
\hline
\end{tabular}

Based on the result of normality above, the criteria of Kolmogorov-Smirnov if significance $>$ 0,05 the data is normally distributed. If significance $<0,05$ the data does not normally distributed. The significance score of pretest is 0,041 which is the score is lower than 0,05 the data in this research is not normally distributed.After the researcher collected the score of pretest, the writer gave treatment for five times meeting and held the posttest to recognize the students' reading comprehension after doing treatment through Team Accelerated Instruction (TAI) technique.

\section{Treatments}

The treatments were given for five meetings after pre-test. The detail of treatment material can be seen from the following table 3 . 
Euis Setiati, Intan Satriani, Teaching Reading Comprehension ...

Table 3.Treatment

\begin{tabular}{|c|c|c|}
\hline \multirow[b]{2}{*}{ No } & \multicolumn{2}{|r|}{ Pre-experimental group } \\
\hline & Date & Material/ Theme \\
\hline 1 & 08-02-2018 & Pre-test \\
\hline 2 & $\begin{array}{l}\text { 15-02-2018 } \\
\text { (Treatment) }\end{array}$ & $\begin{array}{l}\text { Meeting 1: Introducing the treatment team } \\
\text { accelerated instruction (TAI) technique using } \\
\text { narrative text. } \\
\text { Meeting 2: Give the Narrative text "Issumboshi" } \\
\text { using team accelerated instruction technique }\end{array}$ \\
\hline 3 & $\begin{array}{l}\text { 22-02-2018 } \\
\text { (Treatment) }\end{array}$ & $\begin{array}{l}\text { Meeting 3: Give the text "Malin Kundang" using } \\
\text { team accelerated instruction technique } \\
\text { Meeting 4: Give the Narrative text "Strong Wind" } \\
\text { using team accelerated instruction technique }\end{array}$ \\
\hline 4 & $\begin{array}{l}\text { 01-03-2018 } \\
\text { (Treatment) }\end{array}$ & $\begin{array}{l}\text { Meeting 5: Give the Narrative text "The Rats and } \\
\text { The Elephants" using team accelerated instruction } \\
\text { technique }\end{array}$ \\
\hline 5 & 08-03-2018 & Post-test \\
\hline
\end{tabular}

Table above show material during treatments. In implementation of Team Accelerated Instruction (TAI) technique, the researcher divides the students into groups based on their make group different level, gender, and ethnicity. Every group is given the series of specific tasks to be done together, students have to check the answers each other in the group and give assistance each other if needed. The treatments were given for five meetings after pre-test. The students is guided to comprehend the text using team accelerated instruction technique for each meeting. Team Accelerated Instruction (TAI) adapts teaching to individual differences with respect to students' abilities and student achievement. This treatment effects the solving motivational problems in individual teaching techniques, Team Accelerated Instruction (TAI) is designed to derive enormous benefits from the potential socialization contained in learning process.

\section{Posttest Score}

After the students have treatment, the writer given posttest. The test and the scoring were similar with the pre-test. Posttest scores show initial students' reading comprehension after given Team Accelerated Instruction (TAI) technique in treatment part. The detail of students' posttest scores can be seen from the table below: 
Table 4. Scores of Posttest

\begin{tabular}{|c|c|}
\hline Category & Data \\
\hline N (Students) & 34 \\
\hline Highest Score & 90 \\
\hline Lowest Score & 50 \\
\hline Sum & 2305 \\
\hline Mean & 67.79 \\
\hline Std. Deviation & 8.893 \\
\hline
\end{tabular}

Table above shows the score of posttest. After the students have treatment by the writer most students get score higher than the score pretest. The highest score in posttest is 90 and the lowest score is 50 . Total score in posttest is 2305 and the mean score of posttest is 67,79 .

\section{Tests of Normalityfor Pretest Score}

The results of Normality Test of Posttest are presented below:

Table of 5. Normality Test of Posttest

\begin{tabular}{|c|c|c|c|}
\hline \multirow{2}{*}{} & \multicolumn{3}{|c|}{ Kolmogorov-Smirnov ${ }^{\mathrm{a}}$} \\
\cline { 2 - 4 } & Statistic & $\mathrm{df}$ & Sig. \\
\hline posttest & .163 & 34 & .023 \\
\hline
\end{tabular}

The table above shows that the Kolmogorov-Smirnov Normality test were 0.023 which is the value is lower than 0.05 , it can concluded that the null hypothesis is rejected and the data were not normally distributed. Because the data pretest and posttest is not normally distributed, the different test methods used to determine whether there is a difference in score between the posttest and the pretest is a non-parametric difference test, which is the non-parametric difference test of Wilcoxon.

Non- parametric tests are also called distribution-free statistics because they do not require that the data be normally distributed (Tavakoli, 2012). Meanwhile, kind of non-parametric test are Mann-Whitney, Sign Test, Wilcoxon and Mc Nemar. In this research, the writer used Wilcoxon test.

The analysis investigated the Wilcoxon test with the result as follow: 
Euis Setiati, Intan Satriani, Teaching Reading Comprehension ...

Table 6. Result of Non-Parametic Test

Ranks

\begin{tabular}{|c|r|r|r|}
\hline & N & Mean Rank & Sum of Ranks \\
\hline posttest - pretest Negative Ranks & $0^{\mathrm{a}}$ & .00 & .00 \\
Positive Ranks & $30^{\mathrm{b}}$ & 15.50 & 465.00 \\
Ties & $4^{\mathrm{c}}$ & & \\
Total & 34 & & \\
\hline
\end{tabular}

Test Statistics

\begin{tabular}{|lll|r|}
\hline & & & posttest - pretest \\
\hline Z & & & $-4.812^{\mathrm{b}}$ \\
Asymp. Sig. (2-tailed) & & .000 \\
Monte Carlo Sig. (2- & Sig. & .000 \\
tailed) & $95 \%$ Confidence & Lower & .000 \\
& Interval & Bound & \\
& & Upper & .084 \\
& & Bound & .000 \\
Monte Carlo Sig. (1- & Sig. & & .000 \\
& $95 \%$ Confidence & Lower & \\
& Interval & Bound & .084 \\
& & Upper & \\
& & Bound & \\
& & &
\end{tabular}

Based on the result above, it shows the mean rank is 15.50 , sum of rank is 465.00 . The second output is the result of Wilcoxon test for 2 samples dependent that got $Z=-4.812$. Because the hypotheses test for pre-experimental research which is only use one group for pretest-posttest. Then, P-value being used is from Monte-Carlo Sig. (1-tailed) there are 0.000 with criteria hypothesis test if $P$-value $\leq 0.05$, hence $\mathrm{H}_{0}$ is rejected and if $P$-value $\geq 0.05$, hence $\mathrm{H}_{0}$ is accepted. It means teaching reading using Team Accelerated Instruction (TAI) technique can improve students' comprehension.

\section{Discussion}


Based on the results, teaching reading comprehension using Team Accelerated Instruction (TAI) technique can improve students' reading comprehension, it can be seen from table descriptive statistic. The writer found out the mean of pretest 55.59 and after the implementation of Team Accelerated Instruction (TAI) technique, the mean of posttest became 67.79. It shows that there are significant differences between pretest and posttest.Actually, this research has related to the previous studies by Istikhayatun(2015). She believes that Team Accelerated Instruction (TAI) is one of the effective technique to improve students' reading comprehension.

In facts, some other research by (Wiguna, 2017; Purnami, Widodo, \& Prahmana, 2018;Setiani, 2018), they found that Team Accelerated Instruction (TAI) technique can improve another skill in learning process. Team Accelerated Instruction (TAI) technique also helps students to achieve the team goal and encourage students to help another. However, students take final test without teammate's help and teacher gives the score based on their personal achievement. In addition, Team Accelerated Instruction (TAI) is designed to satisfy the criteria for solving the theoretical and practical problems of the individual teaching system. It can minimize teacher involvement in routine examination and management, the teacher was spent at least half of the time to teach small groups, the operations are simple that students can do it and the students were motivated to learn the material given quickly and accurately, the students can check each other, and by making students study in groups with equal status, this technique was built conditions for the formation of positive attitude toward the students which are less academically and among students from different backgrounds or ethnicities. This is supported by the statement from Hamra \& Syatriana (2015). They found that Team Accelerated Instruction (TAI) can improve students' attitude and motivation.

Team Accelerated Instruction (TAI) technique has improved students' reading comprehension. It also motivated the students to more active, innovative, creative, effective and fun learning.

\section{E. CONCLUSION}

Based on the research question the writer concludes that Team Accelerated Instruction (TAI) technique has successfully improved the students' reading comprehension of descriptive text at the 10-AK Students of SMK Pasundan 1 Cimahiin Academic Year of 2017/2018. It is because the mean of pretest 55.59 and after the implementation of Team Accelerated Instruction (TAI) technique the mean of posttest became 67.79. It shows that there are significant differences between pretest and posttest. In other words, the writers' null hypothesis 
Euis Setiati, Intan Satriani, Teaching Reading Comprehension ...

is rejected that teaching reading comprehension using Team Accelerated Instruction (TAI) technique has improve the students' reading comprehension significantly. Therefore, it is suggested to use the TAI in teaching reading comprehension.

\section{REFERENCES}

Creswell, J. W. (2012). Educational Research: Planning, Conducting and Evaluating Quantitative and Qualitative Research. Bandung: Pearson Education Inc.

Depdiknas. (2006). Curriculum for Senior High School Students. Jakarta.

Dornyei, Z. (2007). Research Methods in Applied Linguistics. International Journal of Applied Linguistics. https://doi.org/10.5054/tj.2010.215611

Fraenkel, J. R., Wallen, N. E., \& Hyun, H. H. (2012). How to design and evaluate research in education. New York: McGraw Hill Companies.

Goodman, Y. M. (1980). Reading Strategies Focus on Comprehension. Singapore: B\&J Enterpries PTE Ltd.

Guilford, J. P. (1956). Fundamental Statistics in Psychology and Education. New York: McGraw Hill. Hamra, A., \& Syatriana, E. (2015). Developing a Model of Teaching Reading Comprehension for Efl Students. Teflin Journal, 21(1), 27-40. https://doi.org/10.15639/Teflinjournal.V21I1/27-40

Istikhayatun. (2015). The Use of Team Accelerated Instruction Method to Improve Students' Reading Comprehension.

Kaswan, \& Suprijadi, D. (2013). Research in English Education. Bandung: Putra Praktisi.

Purnami, A. S., Widodo, S. A., \& Prahmana, R. C. I. (2018). The Effect of Team Accelerated Instruction on students ' mathematics achievement and learning motivation. Journal of Physics: Conferences Series, 948. https://doi.org/10.1088/1742-6596/948/1/012020

Setiani, R. (2018). The Implementation of Lesson Study to Improve Student's Vocabulary Mastery Through Team Accelerated Instruction (TAI). Jurnal Elsa, 16(1), 33-38.

Slavin, R. E. (1987). Cooperative Learning: Student Teams. What Research Says to Teacher (Second). Washington DC: National Education Association.

Tarigan, G. (2008). Membaca Sebagai Suatu Keterampilan Berbahasa. Bandung: Angkasa Bandung. Tavakoli, H. (2012). A Dictionary of Research Methodology and Statistics in Applied Linguistics. Tehran: Rahnama Press.

Wiguna, I. G. P. (2017). The Implementation of TAI (Team Accelerated Instruction) in Improving Descriptive Paragraph Writing Ability of the Eighth Grade Students of SMPK 2 Harapan in Academic Year 2016/2017. 